\title{
Role of Pascalization in Milk Processing and Preservation: A Potential Alternative towards Sustainable Food Processing
}

\author{
Muhmmad Farhan Jahangir Chughtai $\left.{ }^{1}{ }^{(}\right)$, Muhammad Adil Farooq ${ }^{1}$, Syeda Aiman Ashfaq ${ }^{1}\left(\mathbb{D}\right.$, Sonia Khan ${ }^{1} \mathbb{(}^{\circ}$, \\ Adnan Khaliq ${ }^{1}$, Sergey Antipov 2,3, Maksim Rebezov 4,5 ${ }^{\circledR}$, Mars Khayrullin ${ }^{2}$, Alla Vorobeva ${ }^{2}$, Elena Nelyubina ${ }^{2}$, \\ Muthu Thiruvengadam ${ }^{6, *(1)}$ and Mohammad Ali Shariati ${ }^{2,4}$ (i)
}

1 Department of Food Science and Technology, Faculty of Engineering and Technology, Khwaja Fareed University of Engineering and Information Technology, Rahimyar Khan 64200, Pakistan;

Farhan.chughtai@kfueit.edu.pk (M.F.J.C.); Adilfarooq9156@gmail.com (M.A.F.); mnsyed25@gmail.com (S.A.A.); soniapk97@gmail.com (S.K.); adnan.khaliq@kfueit.edu.pk (A.K.)

2 Research Department, K.G. Razumovsky Moscow State University of Technologies and Management, 73, Zemlyanoy Val, 109004 Moscow, Russia; s.antipov@mgutm.ru (S.A.); khairullin-mars@ya.ru (M.K.); a1c3@rambler.ru (A.V.); 89049755219@ya.ru (E.N.); shariatymohammadali@gmail.com (M.A.S.)

3 Department of Biophysics and Biotechnology, Voronezh State University, 1 Universitetskaya Ploshchad, 394018 Voronezh, Russia

4 School of Agricultural Sciences, Liaocheng University, 34 Wenhua Road, Liaocheng 252000, China; rebezov@yandex.ru

5 V.M. Gorbatov Federal Research Center for Food Systems of Russian Academy of Sciences, 26 Talalikhina St., 109316 Moscow, Russia

6 Department of Applied Bioscience, College of Life and Environmental Science, Konkuk University, Seoul 05029, Korea

check for updates

Citation: Chughtai, M.F.J.; Farooq, M.A.; Ashfaq, S.A.; Khan, S.; Khaliq, A.; Antipov, S.; Rebezov, M.; Khayrullin, M.; Vorobeva, A.; Nelyubina, E.; et al. Role of Pascalization in Milk Processing and Preservation: A Potential Alternative towards Sustainable Food Processing. Photonics 2021, 8, 498. https:// doi.org/10.3390/photonics 8110498

Received: 12 September 2021

Accepted: 29 October 2021

Published: 8 November 2021

Publisher's Note: MDPI stays neutral with regard to jurisdictional claims in published maps and institutional affiliations.

Copyright: (c) 2021 by the authors. Licensee MDPI, Basel, Switzerland. This article is an open access article distributed under the terms and conditions of the Creative Commons Attribution (CC BY) license (https:/ / creativecommons.org/licenses/by/ $4.0 /)$.
* Correspondence: muthu@konkuk.ac.kr

\begin{abstract}
Renewed technology has created a demand for foods which are natural in taste, minimally processed, and safe for consumption. Although thermal processing, such as pasteurization and sterilization, effectively limits pathogenic bacteria, it alters the aroma, flavor, and structural properties of milk and milk products. Nonthermal technologies have been used as an alternative to traditional thermal processing technology and have the ability to provide safe and healthy dairy products without affecting their nutritional composition and organoleptic properties. Other than nonthermal technologies, infrared spectroscopy is a nondestructive technique and may also be used for predicting the shelf life and microbial loads in milk. This review explains the role of pascalization or nonthermal techniques such as high-pressure processing (HPP), pulsed electric field (PEF), ultrasound (US), ultraviolet (UV), cold plasma treatment, membrane filtration, micro fluidization, and infrared spectroscopy in milk processing and preservation.
\end{abstract}

Keywords: nonthermal processing; high-pressure processing (HPP); pulsed electric field (PEF); ultrasound (US); ultraviolet (UV); cold plasma treatment; infrared spectroscopy

\section{Introduction}

Milk is a nutrient-rich liquid food which comprises carbohydrates, fatty acids, and high-quality proteins with vitamins, minerals, and trace elements [1]. Milk is considered a perishable food due to its high-water contents which help microorganisms to proliferate. Milk and milk products help to prevent arthritis, loss of muscle mass, diabetes mellitus, cardiac disease, cognitive decline, and digestive problems due to their high nutrient content [2]. It is important to thermally process the raw milk before commercialization because it prevents the dairy products from being contaminated by pathogenic bacteria and toxic substances [3]. Thermal processing keeps the aroma, flavor, and texture of food intact by restricting the pathogenic bacteria [4]. Consumers have demanded dairy products that are minimally processed and natural in taste but also have an extended shelf life [5-9]. 
Thermal processing eliminates the microorganisms, but majorly destroys some nutritional components, physical, and chemical properties $[4,10]$, resulting in some undesirable flavor changes, loss of vitamins, and volatile flavor compounds [11]. Nonthermal processing technologies can be used as a substitute for thermal processing due to their ability to provide fresh, nutritious foods that are safe and have a longer shelf life [12,13]. Thermal and non-thermal technologies such as high-pressure processing (HPP), nonthermal plasma (cold plasma), ultrasonic, pulsed electric field (PEF), ultraviolet irradiation, and membrane microfiltration techniques were employed to inhibit the growth of pathogenic microbes [14-22]. The purpose of this review is to provide a brief overview of the use of nonthermal techniques in milk and milk products, including pulsed electric field, ultrasound, ultraviolet, cold plasma treatment, membrane filtration, micro fluidization, and infrared spectroscopy, as well as their effects on the compositional and dietary value of the product.

\section{Review of Literature}

\subsection{High-Pressure Processing (HPP)}

High-pressure processing is a pragmatic substitute for heat handling. It is commercially feasible and allows food processors to pasteurize foods at or near room temperature [23]. The rise in customers' interest in better quality foods is a reason for the development of high-pressure processing as an addition to standard heat treatments [24]. It was examined that high-pressure processing inactivates bacterial spores at high temperatures. HPP can be improved using pressure applications (cyclic, pulsed, or oscillatory), antibacterial agents, and by combining with other treatments. This improvement results in the increased shelf-stability of foods while maintaining the quality and nutritional properties [25]. High-pressure processing has gained huge commercial interest, and a variety of foods treated by HPP that are nutritious and safe have become integral to the international food market [26].

High-pressure processing has other names, such as high hydrostatic pressure (HHP) and pascalization. The research on milk preservation through the application of HPP began a few decades ago [27]. High-pressure treatment of milk produces numerous changes. The most prominent changes are the inactivation of enzymes and microbes, decomposition of whey proteins, and disorganization of casein micelles. Being comparatively expensive does not hinder its commercial importance as it helps achieve certain requirements that were not possible to attain through present thermal processing technologies. Examples include the preservation of dairy products (cheese, yogurt, kefir, and ice cream) without damaging bioactive proteins or important microbes [28].

A table presenting HPP effects on milk enzymes can be found in Table 1. Highpressure processing can inactivate microorganisms; thus, it could be utilized for nonthermal pasteurization of food-producing harmless foodstuffs with sufficient nutritional value and organoleptic attributes. Water is treated as a fluid to transfer pressures to the product between 100 and 1000 megapascals. Usually, commercial systems work between 400 and $700 \mathrm{MPa}$. Pressure does not influence small molecules like pigments, vitamins, amino acids, and volatile compounds because of their simple structures. However, big molecules such as proteins, nucleic acids, enzymes, and polysaccharides may be affected. 
Table 1. Inactivation of microorganisms by high-pressure treatment in milk and milk products.

\begin{tabular}{|c|c|c|c|c|}
\hline Products & Conditions & Target Microorganism & Inactivation Effect & Ref. \\
\hline Skim milk & $\begin{array}{c}\text { Temperature: } 84^{\circ} \mathrm{C} \text {; } \\
\text { pressure: } 300 \mathrm{MPa}\end{array}$ & $\begin{array}{c}\text { Bacillus } \\
\text { stearothermophilus } \\
\text { ATCC } 7953\end{array}$ & 0.67-log reduction & [29] \\
\hline Commercial sterile milk & $\begin{array}{l}\text { Temperature: } 75-85^{\circ} \mathrm{C} \text {; } \\
\text { Pressure: } 300 \mathrm{MPa}\end{array}$ & Bacillus spores & $\begin{array}{l}5-\log \mathrm{CFU} / \mathrm{mL} \\
\text { reduction }\end{array}$ & [30] \\
\hline Commercial sterile milk & $\begin{array}{c}\text { Temperature: } 50^{\circ} \mathrm{C} \text {; } \\
\text { Pressure: } 400 \mathrm{MPa}\end{array}$ & Escherichia coli & $\begin{array}{l}1 \text { min } \mathrm{D} \text { value } \\
\text { reduction }\end{array}$ & [31] \\
\hline Raw milk & $\begin{array}{l}\text { Temperature: } 25^{\circ} \mathrm{C} \text {; } \\
\text { pressure: } 300 \mathrm{MPa}\end{array}$ & Salmonella typhimurium & $\begin{array}{l}9.21 \text { min } \mathrm{D} \text { value } \\
\text { reduction }\end{array}$ & [32] \\
\hline Milk & $\begin{array}{l}\text { Temperature: } 90^{\circ} \mathrm{C} \text {; } \\
\text { pressure: } 700 \mathrm{MPa}\end{array}$ & Clostridium sporogenes & $\begin{array}{l}13.6 \text { min } \mathrm{D} \text { value } \\
\text { reduction }\end{array}$ & [33] \\
\hline Raw milk (15\% milk) & $\begin{array}{l}\text { Temperature: } 24^{\circ} \mathrm{C} \text {; } \\
\text { pressure: } 300 \mathrm{MPa}\end{array}$ & Listeria innocua & 1.80-log reduction & [34] \\
\hline Raw milk (15\% milk) & $\begin{array}{c}\text { Temperature: } 2-4^{\circ} \mathrm{C} \text {; } \\
\text { pressure: } 100 \mathrm{MPa}\end{array}$ & Listeria monocytogenes & 1.20-log reduction & [35] \\
\hline Raw milk (15\% milk) & $\begin{array}{l}\text { Temperature: } 20^{\circ} \mathrm{C} \text {; } \\
\text { pressure: } 300 \mathrm{MPa}\end{array}$ & Staphylococcus aureus & 4.00-log reduction & [36] \\
\hline
\end{tabular}

Much research have been conducted on the implementation of appropriate pressure processing in the processing of milk and dairy products since it is regarded as an appropriate food production technology. In research to see how HPP affected Mató (fresh goat's milk cheese), 500 mega Pascal was applied at $10{ }^{\circ} \mathrm{C}$ or $25^{\circ} \mathrm{C}$ for 5,15 , and $30 \mathrm{~min}$. Physicochemical characteristics such as color, texture, microstructure, whey loss, and changes in composition were assessed. The results showed that the composition remained unchanged, the color and texture of the cheese showed slight changes, and whey from pressure-treated cheese had a higher total nitrogen content. However, no noticeable changes were observed in the microscopic analysis of structure except on the surface of the fresh goat's milk cheese [37].

A study analyzed the impact of HPP on the quality of raw milk, storage, and safety. Different exposure times and pressure levels were assessed alongside artificially inoculated pathogenic L. monocytogenes, Salmonella spp., and E. coli. The study highlighted 5-log reductions for pathogens by HPP. Moreover, HPP increased the raw milk's storage period, preserving its quality attributes and cutting total viable counts, lactic acid bacteria, and Enterobacteriaceae. Furthermore, HPP extended the storage time of raw milk while maintaining its quality characteristics and reducing overall yield, Lactobacilli, and Enterobacteriaceae. As a result, HPP appears to be a viable alternative to traditional raw milk processing [38].

\subsection{Pulsed Electric Field (PEF) Processing}

The food-processing industry is developing new processing methods (such as pulsed electric field, ultrasound, ultraviolet, cold plasma treatment, membrane filtration, and micro fluidization) and products regularly. While food scientists appreciate the advancement of science, consumers are often reluctant to adopt the changes [39]. Pulsed electric field treatment is a new preservation technology with the ability to provide foods with exceptional nutrition, increased shelf life, and better sensory attributes. This includes applying huge electrical currents of 20 to $80 \mathrm{kV} / \mathrm{cm}$ for less than one second at room temperature [40]. The origin of this technique leads back to Germany [41].

Dairy products are mostly applied to examine the impact of pulsed electric field processing. This technique can be a substitute for thermal processing as it can destroy microbes and enzymes and still maintain the originality of food commodities. A few factors affect the efficiency of PEF treatment, which include the treatment time, electricfield intensity, type of enzyme or microorganism, and temperature of food [42]. 
PEF is a nonthermal process, and it is very likely to be successful in the future. There is research aimed at studying the application of PEF to prevent decomposition and inhibit pathogens and enzymes in dairy products. PEF has been acknowledged to successfully decrease the number of pathogens and decomposers in milk. Applying PEF at relatively low temperatures will help achieve desired results, including a decrease in microbial load without damaging the sensory and physico-chemical properties of products [43].

A treatment chamber component, a large electrical pulse generator system, and a pump for immersing liquid food to enable persistent PEF treatment are typical PEF equipment components [44]. High-intensity PEF has gained attention for its capacity to handle fluid commodities and practical usage in uninterrupted movement treating [45]. The use of this technology in industries is still limited due to the lack of reliability of electrical systems. It applies to the fact that more targeted and inexpensive electrical systems are needed to get the maximum benefits from this novel technology [46]. PEF is very likely to help obtain good quality, long-lasting milk, and dairy products with characteristics such as fresh products. It not only limits the activity of most microorganisms but also several enzymes that can be problematic for the safety of the product. There are no findings on the different safety and reliability characteristics of PEF-treated milk products; thus, more research into the safety aspects of PEF is required, which may potentially expose the technology's flaws [47].

Table 2 shows the inactivation of microorganisms by PEFs with moderate heat, as well as key considerations for their application in the milk business. Another study looked at using PEF in combination with light heat processing to extend the shelf life of the whole dairy. Five pulses (2.3 s pulse width and $35 \mathrm{kV} / \mathrm{cm}$ peak electric field intensity) were delivered to whole milk for less than ten seconds at $65^{\circ} \mathrm{C}$. The results showed that milk's shelf life was extended by at least 24 days. PEF and mild heat treatment had a synergistic effect. The inclusion of a thermal regeneration system increased the energy efficiency of the investigated preservation technique [48].

Table 2. Inactivation of microorganisms by pulsed electric field (PEF) processing in milk and milk products.

\begin{tabular}{|c|c|c|c|c|}
\hline Products & Conditions & Target Microorganism & Inactivation Effect & Ref. \\
\hline Milk undergone ultrafiltration & $\begin{array}{l}\text { Pulses: } 50 \text { and } 80 ; \mathrm{kV} / \mathrm{cm} \text { : } \\
60 \text { and } 70\end{array}$ & Escherichia coli & 6 and $9-\log$ & [49] \\
\hline Skim milk (pasteurized) & $200 \mu \mathrm{s} ; \mathrm{kV} / \mathrm{cm}: 50$ & Listeria innocua & 2.6-2.7-log & [50] \\
\hline Ultra-High Temperature milk & $8 \mu \mathrm{s} ; \mathrm{kV} / \mathrm{cm}: 35$ & Staphylococcus aureus & $4.5-\log$ & [51] \\
\hline Skim milk (raw) & $2 \mu \mathrm{s} ; \mathrm{kV} / \mathrm{cm}: 50$ & Listeria innocua & 2.4-log & [52] \\
\hline Whole milk & $43.75 \mu \mathrm{s} ; \mathrm{kV} / \mathrm{cm}: 40$ & Listeria innocua & $5.5-\log$ & [53] \\
\hline Skim milk & $100 \mu \mathrm{s} ; \mathrm{kV} / \mathrm{cm}: 25$ & Staphylococcus aureus & $3-\log$ & [54] \\
\hline
\end{tabular}

\subsection{Ultrasound (US)}

Table 3 summarizes the consequences of ultrasound (US) technology on milk and milk products. Ultrasound is a technology that has been effectively proven for a number of food handling and protection applications. Most of the food processing applications usually suggest fluids. Like any other ultrasound, it is an innovative and useful technology because of its wide array of applications and increasing scientific research. It is being utilized in the food industry for several processes such as drying, homogenization, cutting, tempering, freezing, filtration, degassing, and extraction. It can work as an alternative or promoter to food processing. The usage of ultrasound for food processing has a number of advantages such as increased production rate, reduced energy and temperature, effective mixing, and increased mass transfer. This technology destroys microorganisms and enzymes without effecting nutritional quality or changing organoleptic properties [55]. Ertugay et al. in their study analyzed the effect of ultrasound processing on the homogenization of milk [56]. Milk samples were homogenized with the help of conventional and ultrasonic homogenizers. To evaluate the diameter of fat globules and to determine the homogenization efficiency of milk 
samples a microscope set with a camera and ocular micrometer was used. Results exhibited that ultrasound processing with high power had a vital effect on milk homogenization.

Table 3. Inactivation of microorganisms by ultrasound treatment in milk and milk products.

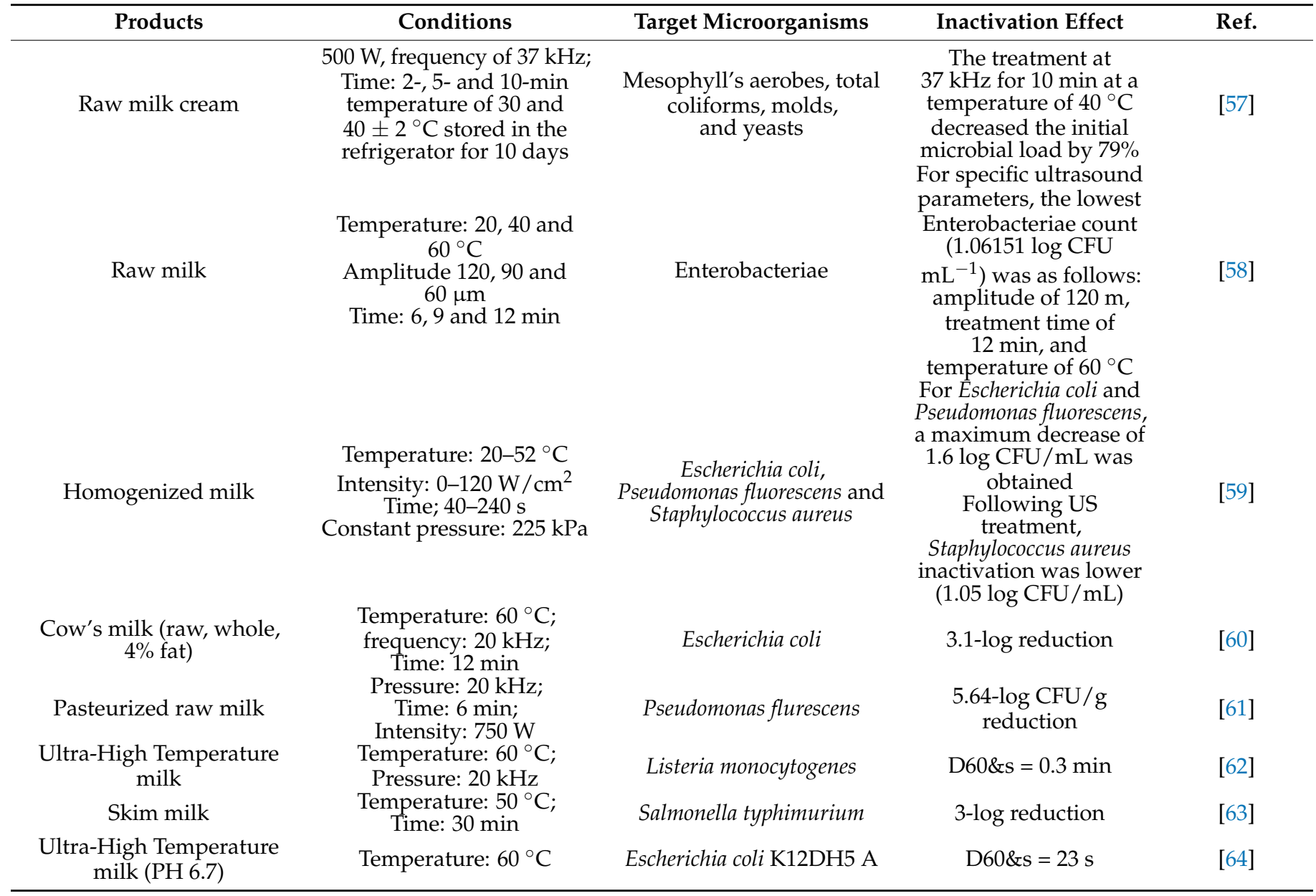

It was seen that exposure times and power levels were directly proportional to homogenization efficiency [56]. The focus of a study on the ultrasonic effect was on simulating milk production characteristics. Based on vitamin C, antioxidant capacity, and the buildup of exopolysaccharides in the final milk product, the effectiveness of ultrasonic processing was assessed. It was derived from the results that showed the reconstitution of dry milk by using ultrasounds increases the nutritional value of the fermented food product and promotes further accumulation of biologically active compounds [65]. Another study examined the influence of ultrasounds on the functional and physical properties of skim milk. Sterilized homogenized skim milk was treated under controlled temperature conditions with a $20 \mathrm{kHz}$ ultrasound at 20 to $41 \mathrm{~W}$. The study highlighted the following effects due to sonication on whey proteins and their aggregates, preservation of the integrity of the casein micelles, disruption of fat globules, and unchanged viscosity [65]. The applications of the ultrasound in the field of food processing involve enzyme and bacterial inactivation as well as the modification and analysis of foods. Currently, the usage of the ultrasound alone for bacterial damage is impractical, whereas its combination with pressure or heat is promising. The future of ultrasound lies in manosonication, thermosonication, and manothermosonication for bactericidal functions. In comparison with traditional heat treatments, sonication is more energy-efficient and reduces enzyme and microbial activity [66]. 


\subsection{Ultraviolet (UV)}

Ultraviolet radiation is a non-ionizing invisible light that lies in the range of the electromagnetic spectrum with a wavelength of 100 to $400 \mathrm{~nm}$, between visible light and X-rays [21]. This technique is preferred for the disinfection and preservation of food, such as liquid food and milk. Its effect is mainly dependent on microbial load, the nature of lenses used, and the infrastructure of the machines [67]. There are three regions of UV light in the electromagnetic spectrum range: ultraviolet light- $A$ that has a wavelength range from 15 to $400 \mathrm{~nm}$; ultraviolet light-B with a wavelength of 280 to $315 \mathrm{~nm}$; and ultraviolet light-C having a wavelength range of 20 to $28 \mathrm{~nm}$. Later UV rays are primarily germicidal against pathogenic and other microorganisms that cause food spoilage, such as viruses and protozoa, which act by disrupting DNA transcription and replication, eventually damaging the DNA and causing cell death $[68,69]$.

A wide variety of food processing and preservation technologies exist. These include crystallization, drying, homogenization, emulsification, dispersion, changing the texture of foods and their solubility, ultrasonication for extraction, and ultraviolet radiation in milk processing [70]. The US Food and Drug Administration (US-FDA) endorsed generating innovation in processing techniques which can accomplish and satisfy the needs for microbial wellbeing in liquid food, most importantly in dairy food products [71]. Table 4 shows the outputs of using UV-light for milk preservation by irradiating the microbial load of milk. Microorganisms were found inactivated in a study in which raw milk was treated with Serratia marcescens, $3.2 \mathrm{~J} / \mathrm{cm}^{2} \mathrm{UV}$-dose at $4{ }^{\circ} \mathrm{C}$ in a collimated system [72]. A UV dose of $1.07 \mathrm{~W} / \mathrm{m}^{2}$ at $5.6^{\circ} \mathrm{C}$ for $60 \mathrm{~s}$ was enough to disable the 7-log of Staphylococcus aureus [73]. Matak et al. [74] stated that UV radiations were used for lowering the L. monocytogenes count that showed positive outputs with the reduction rate by 5-log units in whole goat's milk through the implication of UV (UV dose $158 \pm 16 \mathrm{~J} / \mathrm{m}^{2}$ ). Simmons et al. [75] found a reduction in the full microbial load of 3.5-log in whey with $\mathrm{UV}\left(450 \mathrm{~W} / \mathrm{m}^{2}\right)$ implication. In another study, $1.5 \mathrm{~J} \mathrm{~m} / \mathrm{L}$ ultraviolet radiations were bombarded on cow milk (whole) for the sake of reduction of the microbial load that resulted in a reduction of natural microflora by 3-log [76]. Another study with milk sources of whole cow milk, industrially processed skim and soy milk resulted in the completed deactivation of B. cereus and Escherichia coli studied under the implication of UV reactors (dean flow) [77].

Table 4. Inactivation of microorganisms by ultraviolet (UV) treatment in milk and milk products.

\begin{tabular}{|c|c|c|c|c|}
\hline Products & Conditions & $\begin{array}{c}\text { Target } \\
\text { Microorganism }\end{array}$ & Inactivation Effect & Ref. \\
\hline Raw bulk tank milk & $\begin{array}{l}\text { Temperature: } 4{ }^{\circ} \mathrm{C} \\
\text { Time: } 120 \mathrm{~s}\end{array}$ & S. marcescens & $\begin{array}{l}\text { drop of } 1 \text { log cycle } \\
\text { was achieved }\end{array}$ & [72] \\
\hline Raw milk & $\begin{array}{c}\text { Temperature: } 5.6{ }^{\circ} \mathrm{C} \\
\text { Time: } 60 \mathrm{~s}\end{array}$ & S. aureus & $\begin{array}{c}\text { decline of } 7 \text { log cycles } \\
\text { was achieved }\end{array}$ & [73] \\
\hline Goat skim milk & $\begin{array}{l}\text { Temperature: } 4^{\circ} \mathrm{C} \\
\text { Time: } 18 \mathrm{~s}\end{array}$ & L. monocytogenes & $\begin{array}{l}\text { drop of } 5 \log \text { cycles } \\
\text { was achieved }\end{array}$ & [74] \\
\hline Whey & $\begin{array}{c}\text { Temperature: } 28^{\circ} \mathrm{C} \\
\text { Time: } 100 \mathrm{~s} \\
\text { Intensity: } 450 \mathrm{~W} / \mathrm{m}^{2}\end{array}$ & Overall bacterial load & $\begin{array}{l}\text { drop of } 3.5 \text { log cycles } \\
\text { was achieved }\end{array}$ & [75] \\
\hline Raw cow milk & $\begin{array}{l}4^{\circ} \mathrm{C} \\
\text { Time: } 1.5 \mathrm{~s} \\
0.05 \mathrm{~J} / \mathrm{mL}\end{array}$ & E. coli & $\begin{array}{l}\text { drop of } 4 \log \text { cycles } \\
\text { was achieved }\end{array}$ & [77] \\
\hline Skim milk & $\begin{array}{c}\text { Intensity: } 100 \mathrm{~W}, 20 \mathrm{kHz} \\
\text { Timings: } 7,15 \text {, and } 30 \\
\text { ice bath } \\
\text { Voltage: } 420,900 \text {, and } \\
1800 \mathrm{~J} \mathrm{~mL}^{-1}\end{array}$ & $\begin{array}{c}\text { B. breve } \\
\text { B. infantis, B. longum } \\
\text { (BB-46) and } \\
\text { B.animalis ssp. lactis } \\
\text { (BB-12) }\end{array}$ & $\begin{array}{l}\text { Reduced fermentation time for } \\
\text { B. breve, B.infantis and BB-12 }\end{array}$ & [78] \\
\hline Skimmed cows' milk & $\begin{array}{c}\text { Intensity: } 35 \mathrm{kHz}, 300 \mathrm{~W} \\
\text { Timing: } 5 \mathrm{~min} \\
2.5 \mathrm{~mm} \text { probe }\end{array}$ & Lb. delbrueckii & $\begin{array}{l}\text { drop of } 4 \log \text { cycles } \\
\text { was achieved }\end{array}$ & [79] \\
\hline Cow's milk & $\begin{array}{c}\text { Timings } \\
1-3 \mathrm{~min} \\
\text { Intensity: } 30 \mathrm{kHz} \text { and } 2-8 \mathrm{~W} ; \\
\text { energy density } 4.8-57.6 \mathrm{~J} \mathrm{~mL}^{-1}\end{array}$ & $\begin{array}{l}\text { Lc. lactis subsp. lactis, } \\
\text { Lc. lactis subsp. Cremoris }\end{array}$ & $\begin{array}{l}\text { drop of } 3.5 \log \text { cycles } \\
\text { was achieved }\end{array}$ & [80] \\
\hline
\end{tabular}


Other significant considerations for milk value, for example, the $\mathrm{pH}$, soluble solids, color, and viscosity, have been assessed after being on the UV treatment of milk, with no statistically significant difference in all of these qualities. However, some variations may happen based on the treatment factors, like alterations in the fatty acid report, rises in the thiobarbituric acid-sensitive ingredients, as well as protein sleet $[73,81]$.

\subsection{Cold Plasma Technique}

The electrically energized fourth state of matter in a vaporous form containing ions, free radicals, and some radiation, is called plasma that is produced through electron discharge [82,83]. The plasma state contains almost the same number of chargers, so it is globally assumed to be electrically neutral [84]. When kinetic energy possessed by electrons is increased through the use of high-frequency radio waves, microwaves, thermal or magnetic power, the matter can reach this plasma state, while the kind of plasma depends upon the procedure characteristics and gas secondhand for electron discharge purposes [85]. Plasma was classified into denominated thermal plasma and nonthermal plasma or cold plasma, which can be characterized by the thermodynamics between charged species. Cold plasma requires less power and is produced in vacuum conditions at $30-60{ }^{\circ} \mathrm{C}$. Cold plasma expresses much higher electron temperatures in contrast to the equivalent gas and is unable to show a specific thermal equilibrium [86].

In this treatment, only small energy is gained by charged and uncharged particles while temperature rise is also low, and that is why heat sensitive liquid food products are treated preferably with the cold plasma technique $[84,85]$. Despite this, very high pressure and high power are required for the working of the thermal plasma technique; however, a local thermodynamic equilibrium is present between electrons and high-mass species [87]. The literature described that for all plasma components, the gas temperature is almost the same, which is graded as extremely high [88].

This technique is innovative for food processing specifically to get rid of the microbial load of food that efficiently decreases the shelf life of food, including dairy and non-dairy products [89]. Many agents, such as free radicals and other chemically active species, likely reactive oxygen species, unstable nitrogenous species, and ultraviolet rays with high potential can act during plasma application. These products are the main reasons that cold plasma is preferred for the inactivation of a microbial load because, mostly, they are unable to resist these unstable and reactive species that attack and damage their DNA structures [90].

Table 5 shows the studies in the literature that were conducted to examine the potential of using cold plasma for the purpose of bacterial microfilm inactivation in different states of milk, including skim, semi-skimmed, and whole milk [11,91]. All studies significantly approved the substantial ability of cold plasma to avoid or reduce the number of damaging microorganisms in milk.

Ruan et al. [92] conducted a study to examine the potential of UV for the reduction as well as inactivation of microbes in milk and skim milk that are harmful. Skim milk containing three different microbes, including Salmonella spp., L. monocytogenes, and B. cereus containing a mixture of five, and three strains, respectively, was subjected to cold plasma at 35-40 kV at more than sixty-celsius temperatures. Outcomes revealed a 2.95, 2.74, and $0.18-\log$ decline, respectively. However, in another study, the same strains showed a $5.55,4.36$, and 4.73-log reduction, under the same plasma condition [93]. Further, skim milk, semi-skim milk, and whole milk approved the potential of the cold plasma technique when it showed a reduction of 3.34- $\log$, 3.40-log, and 3.63-log, respectively [94]. Furthermore, another study that used whole, semi-skim, and skim milk as a source containing E. coli, S. aureus, and Salmonella typhimurium subjected to characteristic parameters of plasma techniques (AC power supply $20 \mathrm{kV}$ ) after being stored for 40 days at $4{ }^{\circ} \mathrm{C}$ expressed reduction to $3.63,2.00$, and 2.62 colony-forming units per milliliter, respectively. 
Table 5. Inactivation of microorganisms by cold plasma treatment in milk and milk products.

\begin{tabular}{|c|c|c|c|c|}
\hline Products & Conditions & $\begin{array}{c}\text { Target } \\
\text { Microorganism }\end{array}$ & Inactivation Effect & Ref. \\
\hline Raw milk & $\begin{array}{l}\text { Temperature: } 35^{\circ} \mathrm{C} \\
\text { Time: } 20 \mathrm{~min} \\
\text { Intensity: } 9 \mathrm{kV}\end{array}$ & $\begin{array}{l}\text { Escherichia coli } \\
\text { (ATCC 25922) }\end{array}$ & $\begin{array}{c}\text { drop of } 3.63 \text { log cycles } \\
\text { was achieved }\end{array}$ & [11] \\
\hline Milk & $\begin{array}{l}\text { Intensity: } 250 \mathrm{~W} \\
\text { Time } 10 \mathrm{~min} \\
\text { Temperature: } 25^{\circ} \mathrm{C}\end{array}$ & $\begin{array}{c}\text { E. coli (KCTC 1682) } \\
\text { L. monocytogenes } \\
\text { (KCTC 3569) } \\
\text { S. typhimurium } \\
\text { (KCTC 1925) }\end{array}$ & $\begin{array}{c}\text { drop of } 2.40 \text { log cycles } \\
\text { was achieved }\end{array}$ & [91] \\
\hline$x^{2}$ & $\begin{array}{l}\text { Intensity: } 35-40 \mathrm{kV} \\
\text { Temperature }<60{ }^{\circ} \mathrm{C} \text {, } \\
\text { Single pass } \mathrm{CHIEF}\end{array}$ & $\begin{array}{c}\text { E. coli O157:H7 ATCC } 43895 \\
\text { Salmonella ( } 5 \text { strain mixture) } \\
\text { L. monocytogenes } \\
\text { (5 strain mixture) }\end{array}$ & $\begin{array}{l}\text { drop of } 2.95 \text { log cycles } \\
\text { was achieved for E. coli } \\
\text { O157:H7 ATCC } 43895 \\
\text { reduction of } 2.74 \text { log } \\
\text { cycles was achieved for } \\
\text { Salmonella } \\
\text { ( } 5 \text { strain mixture }) \\
\text { reduction of } 0.18 \text { log } \\
\text { cycles was achieved for } \\
\text { L. monocytogenes } \\
\text { drop of } 4.73 \text { log cycles }\end{array}$ & [92] \\
\hline Skim milk & $\begin{array}{c}\text { Intensity } 35-40 \mathrm{kV}, \\
\text { exit temperature }<60{ }^{\circ} \mathrm{C}, \\
\text { double pass } \mathrm{CHIEF}\end{array}$ & $\begin{array}{l}\text { E. coli O157:H7 } \\
\text { (5 strain mixture) } \\
\text { Salmonella spp. } \\
\text { (5 strain mixture) } \\
\text { L. monocytogenes } \\
\text { (5 strain mixture) }\end{array}$ & $\begin{array}{c}\text { was achieved for E. coli } \\
\text { O157:H7 } \\
\text { drop of } 4.36 \text { log cycles } \\
\text { was achieved for } \\
\text { Salmonella } \\
\text { drop of } 5.55 \text { log cycles } \\
\text { was achieved for } \\
\text { monocytogenes }\end{array}$ & {$[93,94]$} \\
\hline Raw skim milk & $\begin{array}{l}\text { Intensity: } 30-40 \mathrm{kV} \\
\text { One to thirty pulses } \\
\text { Temperature: } 20-72{ }^{\circ} \mathrm{C}\end{array}$ & Listeria innocua & drop of $4.3 \log$ & [53] \\
\hline Skim milk & $\begin{array}{c}\text { Intensity: } 40 \mathrm{kV} \mathrm{cm} 1 \\
4937 \text { microsecond PEF plus UV }\end{array}$ & $\begin{array}{c}\text { Listeria innocua, } \\
\text { Zygosaccharomyces bailii }\end{array}$ & $\begin{array}{l}\text { (3.0-5.0 log reductions) } \\
(7.9-8.8 \log \text { reductions }\end{array}$ & [95] \\
\hline
\end{tabular}

Various factors are involved in the working potential of cold plasma for the removal of microbes from food, especially milk, including strains of bacteria that are required to be inactivated, voltage, duration, the composition of the gas used, and food chemistry. Cold plasma technology's antimicrobial efficacy in dairy products is influenced by a number of parameters, including the target microorganism's species, input power, treatment time, gas composition, and food composition. The literature results showed cold plasma as a forthcoming innovative technique in contrast to the previously used techniques for milk processing because there are very few changes in color and flavor that may cause a reduction in commercial value $[11,96]$. However, the various results give directions to the researchers for further innovations in technique parameters for commercial productions [91].

\subsection{Membrane Filtration}

Membrane filtration is essentially an extraction method that significantly deals with membranes that are specialized for filtration of selective components like dust particles as well as certain sized microbes, to focus on fractionating fluids into various compositions. The retentate is referred to as a retained fluid and permeate is passed out of the liquid. The efficacy of membranes is particularly assessed by the pressure and amount of liquid across the membrane. Since 1960, the dairy sector has used membrane filtration technology [97]. In the foodstuff trade, mainly in dairy commercialization, membrane filtration processes, either nanofiltration or ultrafiltration, are preferred for efficient protein separation or 
purification [98]. It acts on the side of their fertility to lower the complete viable count of microorganisms, thereby extending the shelf life without compromising the nutritional and sensory characteristics of dairy products [97].

Table 6 summarizes the inactivation of microorganisms and bacteria in milk in order to preserve it for a long period and make it easier to handle or process for different dairy products. It is formed by the membrane microfiltration of milk. Pafylias et al. [99] observed the potential to reduce the microbial count from treated skim milk via membrane filtration, particularly on an ironic membrane with a hole size of 1.4 microns. It was also summarized that lessening of the microbe number, particularly in skim milk, is possible to obtain the exclusive use of any discriminative alterations in milk biochemistry.

It was investigated that the membrane filtration method has the potency to get rid of microbiota, vegetative spores, and other actively fertile cells from skim milk at decreased temperatures. They detected no bacteria in skim milk permeate that was initially having a count of 5.25 and 2.15-log colony-forming units per milliliter, of vegetative microbes and spores, respectively, under membrane filtration treatment conditions such as $1.4 \mu \mathrm{m}$ pore size at $6{ }^{\circ} \mathrm{C}$, while the somatic cell's viable count was also observed to be reduced by up to 3.0-log. The researcher observed a 2.1-log decrease in mesophile microbes in low-fat milk when treated through the crossflow membrane filtration [100]. Another author reported a significant reduction in vegetative cells $(>3.5-\log )$, spore formation $(>4.5-\log )$, and free somatic cells of microbes under specific treatment conditions [101].

Gosch et al. [102] examined more efficient microbial removal and reduction up to $>2.5$ by using a membrane having a pore size of $0.8 \mu \mathrm{m}$ than the MF with a membrane pore size of $1.4 \mu \mathrm{m}$ that showed more than a 3.5-log lessened viable number. In combination, both types of the membrane caused a reduction in the complete sustainable number up to 2.3- $\log$ CFU / mL in milk. Results also revealed that both membranes caused the complete removal of microbes from food sources either with an aperture size of 0.14 or 0.2 . The research study conducted by Daufin et al. [103] proved that reducing bacterial numbers to 4.13-log cycles in the skim milk processed it under the following MF conditions: pore size of $1.4 \mu \mathrm{m}$, temp. $51{ }^{\circ} \mathrm{C}$. Another study applied a $1.4 \mu \mathrm{m}$ porcelain membrane with a hole size of 1.4 micrometers. This was an MF treatment for the sake of checking the potency of membrane filtration in the removal of the microbes and spores from milk [104]. A microbial viable count reduction of 2.1 to $3.1-\log C F U / \mathrm{mL}$ has also been reported bypassing the milk through $1.4 \mu \mathrm{m}$ of the microbial filter as compared to the initial value of the microbiome. On the other side, the ceramic membrane of the same pore size reduced the value up to 2-3-log [105]. A microbial reduction of 5 to $6-\log$ and 3 to $4-\log C F U / m L$ occurred through Sterilox ${ }^{\circledR}$ membranes using 0.8 and $1.4 \mu \mathrm{m}$ MF, which is much more efficient than the former. Elwell and Barbano [106] investigated the potency of a method by using membranes made of ceramic with pore sizes of 1.4 micrometers for preservation purposes and found that bacterial counts were 3.79-log. A study investigated the shelf life of skim milk preserved through the membrane filtration method and found more than 4.5-log reductions. In addition, as compared to the number of microbes in the milk before treatment, the microbial value was reduced to a negligible level [107]. Another study investigated skim milk preservation by using membrane filtration and observed a lessened bacterial load up to $>3.5-\log$, in contrast to the outcomes when the 0.5 -micrometer membrane was used, and the bacterial number of the viable count was increased to 2-3$\log$ [108]. In another scientific study by Brans et al. [109], they observed that B. subtilis was minimized in number up to 6.6-log by using a membrane that has a narrow pore size such as $0.5 \mu \mathrm{m}$ micro-sieve and could act at a low pressure of the transmembrane. 
Table 6. Inactivation of microorganisms by membrane filtration treatment in milk and milk products.

\begin{tabular}{|c|c|c|c|c|}
\hline Product & Conditions & $\begin{array}{c}\text { Target } \\
\text { Microorganism }\end{array}$ & Inactivation Effect & Ref. \\
\hline Skim milk & $\begin{array}{c}\text { MF-1.4 } \mu \mathrm{m} \text {, ceramic } \\
\text { membrane, } \\
\mathrm{Tp}=50{ }^{\circ} \mathrm{C}\end{array}$ & $\begin{array}{l}\text { Full microbial } \\
\text { load }\end{array}$ & $\begin{array}{c}\text { drop of } 4.5 \mathrm{log} \\
\text { cycles was achieved }\end{array}$ & [99] \\
\hline Simulated milk & $1.4 \mu \mathrm{m}$ at $6^{\circ} \mathrm{C}$ & Full microbiome & $\begin{array}{c}\text { drop of } 3 \log \text { cycles } \\
\text { was achieved }\end{array}$ & [100] \\
\hline Skim milk & $\begin{array}{c}55^{\circ} \mathrm{C}, 1.4 \mu \mathrm{m} \\
\text { pore size }\end{array}$ & $\begin{array}{c}\text { Bacterial } \\
\text { vegetative, } \\
\text { spore-forming, } \\
\text { and somatic cells }\end{array}$ & $\begin{array}{c}\text { drop of }>3.5,>4.5, \\
\text { and no } \log \text { cycles } \\
\text { were achieved }\end{array}$ & [101] \\
\hline Skim milk & $\begin{array}{c}0.8 \mu \mathrm{m}, \text { tubular } \\
\text { ceramic ISOFLUX } \\
\text { membrane }\end{array}$ & $\begin{array}{c}\text { Total bacterial } \\
\text { load }\end{array}$ & $\begin{array}{c}\text { drop of }>2.3 \log \\
\text { cycles was achieved }\end{array}$ & [102] \\
\hline Skim milk & $\begin{array}{l}1.14 \mu \mathrm{m} \text { ceramic } \\
\text { membrane }\end{array}$ & Total bacteria & $\begin{array}{c}\text { drop of } 3.1 \mathrm{log} \\
\text { cycles was achieved }\end{array}$ & [104] \\
\hline
\end{tabular}

\subsection{Micro Fluidization}

Micro fluidization is a revolutionary technique of the nonthermal procedure. Proficiently in one pass, the milk homogenizes into an emulsion inhabited through the components with changed protein-protein as well as protein-fat interactions and submicron-sized fat droplets. Micro fluidization is a procedure that is proposed for milk with two streams smashing together at an angle of $180^{\circ}$ [110]. To the milk, the main alterations are persuaded when milk's two streams are enforced (up to $200 \mathrm{MPa}$ ) under elevated pressure within a reaction chamber to smash together in opposing directions, as well as the resultant hurly-burly, cavitation, and shear disrupt of the droplet of lipid and its adjacent membrane. When compared to the homogenization of lower pressure, the micro fluidized milk has minor-sized lipid droplets at the lipid interface through a smaller amount of intact or semi-intact casein micelles. A few of the smaller lipid droplets in fact are entrenched in a micelle portion [111]. Micro fluidization has been utilized to improve the yogurt texture and manufacturing [112]; however, micro fluidized milk forms denser, fewer supple cheese matrices, which are harmful to the mozzarella and cheddar cheeses' textures $[113,114]$. However, immediately after the micro fluidization on the milk explosive profiles, no information is obtainable. In milk, the fat droplets' severe disruption is of concern as to the flavor of milk. The components of fatty acids are major contributors as well as extremely vulnerable to rancidity issues, oxidative (aldehydes) and (free fatty acids) hydrolytic. The ultrahigh-pressure homogenization (UHPH), which utilizes a homogenization nozzle at $>200 \mathrm{MPa}$ pressure, was reported to alter the milk aroma [115] as well as yogurts [116,117], and in aging cheeses to change the lipolysis and proteolysis [118]. Hardly any studies have assessed the volatile profile in UHPH milk $[119,120]$. Prepared within micro fluidized milk in cheese it was noticed that there is no alter in milk composition except for a minor lessening in protein. The fat droplet size was abridged, a good emulsion was noticed by confocal microscopy by scattered agglomerations. Milk coagulation possessions treated at $54{ }^{\circ} \mathrm{C}$ as well as 125 or $170 \mathrm{MPa}$ have exposed extended times of coagulation as well as weaker gels. As for micro fluidized milk in the gels form, an opaque matrix with well-dispersed droplets of fat-protein was observed [121]. The micro fluidization decreased globule sized milk fat as well as a number of globules' multiplication, and the cheeses prepared as of micro fluidized cream were superior in moisture and softer in texture. The enlarged cheese yield had been allocated additional fat and moisture retention [113]. The cheese milk micro fluidization demonstrated a reduction in the mozzarella cheese's aptitude to melt and flow. The cheese milk micro fluidization reduced the droplet size of lipid, enhanced the small lipid droplet allocation, as well as entrenched the smaller-sized drops into the matrix of protein, and transformed the interactions of fat with protein and the mozzarella cheese's rheological possessions [114]. In additional work, it has been established that there 
was no major difference in opus or microstructure among the mozzarella prepared as no homogenized milk as well as milk was homogenized at $10-30{ }^{\circ} \mathrm{C}$ and 34 megapascal as this temperature does not adequately turn to liquid the fat on behalf of whole micro fluidization, as well as this pressure does not decrease the size of the fat globules. In the cheese, the fat globules turned out to be smaller at elevated temperatures and pressures [122]. When micro fluidization was applied to the milk to make frozen products, diverse pressures had an effect on a few frozen dairy desserts' possessions. Nonfat as well as low-fat ice creams prepared with micro fluidized milk showed slower rates of meltdown [123]. It has been established that the thermally denatured whey proteins can be incompletely or completely solubilized by micro fluidization as well as being able to reduce the heat-treated whey protein sedimentation [124]. It has been exposed that dynamic high-pressure micro fluidization is able to persuade the $\beta$-Lacto globulin antigenicity in bovine milk that was carried about through changes in $\beta$ strand content, particle size, and SH groups [125]. For micro fluidized milk's changed functionalities as innovative dairy food applications are explored, the micro fluidization's instant effect on the explosive compound profile of the milk, a crucial factor in user receipt of the product, requires additional clarification.

\subsection{Infrared Spectroscopy}

Infrared spectroscopy is widely being used for verifying adulteration and authenticity in foods [126]. It is one of the most pertinent technologies in process control, analysis of raw materials, and characteristics of final products in the dairy industry [127]. Techniques such as NIR (near-infrared) and MIR (mid-infrared) have been productively applied in the evaluation of milk and dairy products' quality, including whey, cheese, WPCs, and milk powder. During routine liquid milk testing, FT-MIR is the global method of choice for composition and quality control. It helps with speedy, non-destructive quantification of milk chemical properties to elude reference methods, which are usually costly, tiresome, and time-consuming [128]. Mid-infrared displays distinct bands for organic functional groups, protein, fat, and lactose which are constituents of milk and are good for quantitative and qualitative identification [129]. As compared to the NIR apparatus, medium infrared equipment usually uses the smallest possible sample volume for the milk analysis. However, its major drawback is the occurrence of an enormous band of absorption of water, since milk has about $87 \%$ water [130]. Another disadvantage of FT-MIR is the experimental complexity for the milk analysis and the requirement for sample preparation (in the absence of ATR) [129]. Mid-infrared devices are commonly much more expensive. The NIR has several advantages over the MIR such as a cheaper light source and simple and economical transmission instruments with glass optics. Botelhoet et al. [131] were able to perform the simultaneous detection of five adulterants in raw cow milk by using a multivariate classification and mid-infrared spectroscopy. The adulterants were water, sucrose, starch, formaldehyde, and sodium citrate. For every adulterant, a particular area of the spectrum differentiates from the original milk spectrum according to the observations made. A distinct peak of about $1000 \mathrm{~cm}^{-1}$ could be noted for formaldehyde adulteration. Moreover, in sucrose adulteration, several peaks appeared near $1200-1000 \mathrm{~cm}^{-1}$ in the fingerprint region. Gondim et al. [132] investigated a sequential strategy in the same line of research for the detection of usual adulterants in milk. These included thickeners, neutralizing agents, preservatives, and water. The classification technique SIMCA (Soft Independent Modelling of Class Analogy) was applied to mid-infrared (MIR) data and the cross-validation method was used for building models.

Residues of some veterinary drugs such as enrofloxacin, ceftiofur hydrochloride, tetracycline, penicillin, and diclofenac sodium were analyzed in milk samples by using PCA-associated FT-NIR for fast and accurate detection [130]. The results helped to distinguish different types of antimicrobics dissolved in milk. These were compared with the maximum residue limits approved by the European Medicines Agency and the Ministry of Agriculture, Livestock and Supply of Brazil. Spectroscopy procedures have been used in research with whey and its products [133-139]. O'Loughlin et al. [136] character- 
ized the alterations going on in whey protein dispersions due to heat treatment. They examined the thermal denaturation of whey protein solutions and performed inter- and intramolecular level analyses using infrared spectroscopy. According to the researchers, infrared (IR) spectroscopy for distinguishing between $2^{\circ}$ and $3^{\circ}$ protein structures is fast and reasonable when compared to other methods. The results revealed that MIR is a useful technique in differentiating the structural changes in homogeneous protein systems relating to physical properties.

\section{Conclusions}

Pascalization or nonthermal techniques including high-pressure processing, ultrasound, micro fluidization, ultraviolet radiation, cold plasma technique, microfiltration, and infrared spectroscopy have the potential to be used in milk and milk products. These techniques not only inactivate the vegetative microorganisms in foods but also have a slight effect on the sensory and nutrient value of foodstuffs. These techniques are being used as a substitute for thermal techniques in the milk industry because of their promising effects on the processing of dairy food sources. Despite the various beneficial effects of these technologies on dairy food items, including milk and products made from milk, dairy industries still feel reluctant to adopt nonthermal technologies due to their high cost and large production value.

Author Contributions: Conceptualization, M.F.J.C. and A.K.; methodology, S.K., M.A.F. and S.A.A.; collection of literature, reviewing, and editing, S.A., M.R., M.K., A.V., E.N., M.T. and M.A.S. All authors have read and agreed to the published version of the manuscript.

Funding: This research work was supported by a grant from the Ministry of Science and Higher Education of the Russian Federation (under Agreement No 075-11-2019-044 of 27 November 2019).

Acknowledgments: The authors are highly grateful to the Department of Food Science and Technology for their contribution.

Conflicts of Interest: The authors declare that they have no conflict of interest.

\section{References}

1. Coutinho, N.M. Cold plasma processing of milk and dairy products. Trends Food Sci. Technol. 2018, 74, 56-68. [CrossRef]

2. Hess, J.M.; Jonnalagadda, S.S.; Slavin, J.L. Dairy foods: Current evidence of their effects on bone, cardiometabolic, cognitive, and digestive health. Compr. Rev. Food Sci. Food Saf. 2016, 15, 251-268. [CrossRef] [PubMed]

3. Amaral, G.; Silva, E.K.; Cavalcanti, R.N.; Cappato, L.P.; Guimaraes, J.T.; Alvarenga, V.O.; Esmerino, E.A.; Portela, J.B.; Ana, A.S.S.; Freitas, M.Q.; et al. Dairy processing using supercritical carbon dioxide technology: Theoretical fundamentals, quality and safety aspects. Trends Food Sci. Technol. 2017, 64, 94-101. [CrossRef]

4. Barba, F.J.; Esteve, M.J.; Frígola, A. High pressure treatment effect on physicochemical and nutritional properties of fluid foods during storage: A review. Compr. Rev. Food Sci. Food Saf. 2012, 11, 307-322. [CrossRef]

5. Roobab, U.; Aadil, R.M.; Madni, G.M.; Bekhit, A.E. The impact of nonthermal technologies on the microbiological quality of juices: A review. Compr. Rev. Food Sci. Food Saf. 2018, 17, 437-457. [CrossRef] [PubMed]

6. Aadil, R.M.; Zeng, X.A.; Zhang, Z.H.; Wang, M.S.; Han, Z.; Jing, H.; Jabbar, S. Thermosonication: A potential technique that influences the quality of grapefruit juice. Int. J. Food Sci. Technol. 2015, 50, 1275-1282. [CrossRef]

7. Aadil, R.M.; Zeng, X.A.; Wang, M.S.; Liu, Z.W.; Han, Z.; Zhang, Z.H.; Hong, J.; Jabbar, S. A potential of ultrasound on minerals, micro-organisms, phenolic compounds and colouring pigments of grapefruit juice. Int. J. Food Sci. Technol. 2015, 50, 1144-1150. [CrossRef]

8. Mir, S.A.; Shah, M.A.; Mir, M.M. Understanding the role of plasma technology in food industry. Food Bioproc. Technol. 2016, 9, 734-750. [CrossRef]

9. Ahmad, T.; Aadil, R.M.; Ahmed, H.; ur Rahman, U.; Soares, B.C.; Souza, S.L.; Pimentel, T.C.; Scudino, H.; Guimarães, J.T.; Esmerino, E.A.; et al. Treatment and utilization of dairy industrial waste: A review. Trends Food Sci. Technol. 2019, 88, 361-372. [CrossRef]

10. Mosqueda-Melgar, J.; Elez-Martinez, P.; Raybaudi-Massilia, R.M.; Martin-Belloso, O. Effects of pulsed electric fields on pathogenic microorganisms of major concern in fluid foods: A review. Crit. Rev. Food Sci. Nutr. 2008, 48, 747-759. [CrossRef]

11. Gurol, C.; Ekinci, F.Y.; Aslan, N.; Korachi, M. Low temperature plasma for decontamination of E. coli in milk. Int. J. Food Microbiol. 2012, 157, 1-5. [CrossRef] 
12. Alegbeleye, O.O.; Guimarães, J.T.; Cruz, A.G.; Sant'Ana, A.S. Hazards of a 'healthy'trend? An appraisal of the risks of raw milk consumption and the potential of novel treatment technologies to serve as alternatives to pasteurization. Trends Food Sci. Technol. 2018, 82, 148-166. [CrossRef]

13. Li, X.; Farid, M. A review on recent development in non-conventional food sterilization technologies. J. Food Eng. 2016, 182, 33-45. [CrossRef]

14. Claeys, W.L.; Cardoen, S.; Daube, G.; De Block, J.; Dewettinck, K.; Dierick, K.; De Zutter, L.; Huyghebaert, A.; Imberechts, H.; Thiange, P.; et al. Raw or heated cow milk consumption: Review of risks and benefits. Food Control 2013, 31, 251-262. [CrossRef]

15. Amaral, G.V.; Silva, E.K.; Costa, A.L.; Alvarenga, V.O.; Cavalcanti, R.N.; Esmerino, E.A.; Guimarães, J.T.; Freitas, M.Q.; Sant'Ana, A.S.; Cunha, R.L.; et al. Whey-grape juice drink processed by supercritical carbon dioxide technology: Physical properties and sensory acceptance. LWT 2018, 92, 80-86. [CrossRef]

16. Guimarães, J.T.; Silva, E.K.; Alvarenga, V.O.; Costa, A.L.; Cunha, R.L.; Sant'Ana, A.S.; Freitas, M.Q.; Meireles, M.A.; Cruz, A.G. Physicochemical changes and microbial inactivation after high-intensity ultrasound processing of prebiotic whey beverage applying different ultrasonic power levels. Ultrason. Sonochem. 2018, 44, 251-260. [CrossRef]

17. Guimarães, J.T.; Silva, E.K.; Ranadheera, C.S.; Moraes, J.; Raices, R.S.; Silva, M.C.; Ferreira, M.S.; Freitas, M.Q.; Meireles, M.A.; Cruz, A.G. Effect of high-intensity ultrasound on the nutritional profile and volatile compounds of a prebiotic soursop whey beverage. Ultrason. Sonochem. 2019, 55, 157-164. [CrossRef] [PubMed]

18. Coutinho, N.M.; Silveira, M.R.; Fernandes, L.M.; Moraes, J.; Pimentel, T.C.; Freitas, M.Q.; Silva, M.C.; Raices, R.S.; Ranadheera, C.S.; Borges, F.O.; et al. Processing chocolate milk drink by low-pressure cold plasma technology. Food Chem. 2019, 278, $276-283$. [CrossRef]

19. Coutinho, N.M.; Silveira, M.R.; Pimentel, T.C.; Freitas, M.Q.; Moraes, J.; Fernandes, L.M.; Silva, M.C.; Raices, R.S.; Ranadheera, C.S.; Borges, F.O.; et al. Chocolate milk drink processed by cold plasma technology: Physical characteristics, thermal behavior and microstructure. LWT 2019, 102, 324-329. [CrossRef]

20. Zia, S.; Khan, M.R.; Zeng, X.A.; Shabbir, M.A.; Aadil, R.M. Combined effect of microwave and ultrasonication treatments on the quality and stability of sugarcane juice during cold storage. Int. J. Food Sci. Technol. 2019, 54, 2563-2569. [CrossRef]

21. Aadil, R.M.; Khalil, A.A.; Rehman, A.; Khalid, A.; Inam-ur-Raheem, M.; Karim, A.; Gill, A.A.; Abid, M.; Afraz, M.T. Assessing the impact of ultra-sonication and thermo-ultrasound on antioxidant indices and polyphenolic profile of apple-grape juice blend. J. Food Process. Preserv. 2020, 44, e14406. [CrossRef]

22. Aadil, R.M.; Zeng, X.A.; Han, Z.; Sahar, A.; Khalil, A.A.; Rahman, U.U.; Khan, M.; Mehmood, T. Combined effects of pulsed electric field and ultrasound on bioactive compounds and microbial quality of grapefruit juice. J. Food Process. Preserv. 2018, 42, e13507. [CrossRef]

23. Balasubramaniam, V.; Farkas, D. High-pressure food processing. Food Sci. Technol. Int. 2008, 14, 413-418. [CrossRef]

24. Huang, H.W.; Wu, S.J.; Lu, J.K.; Shyu, Y.T.; Wang, C.Y. Current status and future trends of high-pressure processing in food industry. Food Cont. 2017, 72, 1-8. [CrossRef]

25. Zhang, H.; Mittal, G.S. Effects of high-pressure processing (HPP) on bacterial spores: An overview. Food Rev. Int. 2008, 24, 330-351. [CrossRef]

26. Bull, M.K.; Hayman, M.M.; Stewart, C.M.; Szabo, E.A.; Knabel, S.J. Effect of prior growth temperature, type of enrichment medium, and temperature and time of storage on recovery of Listeria monocytogenes following high pressure processing of milk. Int. J. Food Microbiol. 2005, 101, 53-61. [CrossRef] [PubMed]

27. Mandal, R.; Kant, R. High-pressure processing and its applications in the dairy industry. Food Sci. Technol. 2017, 1, 33-45.

28. Huppertz, T. High pressure processing of milk. In Improving the Safety and Quality of Milk; Elsevier: Amsterdam, The Netherlands, 2010; pp. 373-399.

29. Pinho, C.R.; Franchi, M.A.; Tribst, A.A.; Cristianinia, M. Effect of high-pressure homogenization process on Bacillus stearothermophilus and Clostridium sporogenes spores in skim milk. Procedia Food Sci. 2011, 1, 869-873. [CrossRef]

30. Amador Espejo, G.G.; Hernández-Herrero, M.M.; Juan, B.; Trujillo, A.J. Inactivation of Bacillus spores inoculated in milk by ultra-high-pressure homogenization. Food Microbiol. 2014, 44, 204-210. [CrossRef]

31. Gervilla, R.; Felipe, X.; Ferragut, V.; Guamis, B. Effect of high hydrostatic pressure on Escherichia coli and Pseudomonas fluorescens strains in bovine milk. J. Dairy Sci. 1997, 80, 2297-2303. [CrossRef]

32. Erkmen, O. Mathematical modeling of Salmonella typhimurium inactivation under high hydrostatic pressure at different temperatures. Food Bioprod. Process. 2009, 87, 68-73. [CrossRef]

33. Shao, Y.; Ramaswamy, H.S. Clostridium sporogenes-ATCC 7955 spore destruction kinetics in milk under high pressure and elevated temperature treatment conditions. Food Bioproc. Technol. 2011, 4, 458-468. [CrossRef]

34. Picart, L.; Thiebaud, M.; René, M.; Pierre Guiraud, J.; Cheftel, J.C.; Dumay, E. Effects of high pressure homogenisation of raw bovine milk on alkaline phosphatase and microbial inactivation: A comparison with continuous short-time thermal treatments. J. Dairy Res. 2006, 73, 454-463. [CrossRef] [PubMed]

35. Iucci, L.; Patrignani, F.; Vallicelli, M.; Guerzoni, M.E.; Lanciotti, R. Effects of high pressure homogenization on the activity of lysozyme and lactoferrin against Listeria monocytogenes. Food Control 2007, 18, 558-565. [CrossRef]

36. Briñez, W.J.; Roig-Sagués, A.X.; Herrero, M.M.H.; López, B.G. Inactivation of Staphylococcus ssp. Strains in whole milk and orange juice using ultra high-pressure homogenization at inlet temperatures of 6 and 20 ${ }^{\circ}$. Food Control 2007, 18, 1282-1288. [CrossRef] 
37. Capellas, M.; Mor-Mur, M.; Sendra, E.; Guamis, B. Effect of high-pressure processing on physico-chemical characteristics of fresh goats' milk cheese (Mató). Int. Dairy J. 2001, 11, 165-173. [CrossRef]

38. Stratakos, A.C.; Inguglia, E.S.; Linton, M.; Tollerton, J.; Murphy, L.; Corcionivoschi, N.; Koidis, A.; Tiwari, B.K. Effect of high pressure processing on the safety, shelf life and quality of raw milk. Innov. Food Sci. Emerg. Technol. 2019, 52, 325-333. [CrossRef]

39. Olsen, N.V.; Grunert, K.G.; Sonne, A.M. Consumer acceptance of high-pressure processing and pulsed-electric field: A review. Trends Food Sci. Technol. 2010, 21, 464-472. [CrossRef]

40. K Kumar, Y.; Patel, K.K.; Kumar, V. Pulsed electric field processing in food technology. Int. J. Eng. Stud. Technol. Approach 2015, 1, 6-17.

41. Barbosa-Cánovas, G.V.; Zhang, Q.H. Pulsed Electric Fields in Food Processing: Fundamental Aspects and Applications; CRC Press: Boca Raton, FL, USA, 2019.

42. Bendicho, S.l.; Barbosa-Cánovas, G.V.; Martín, O. Milk processing by high intensity pulsed electric fields. Trends Food Sci. Technol. 2002, 13, 195-204. [CrossRef]

43. Munekata, P.E.; Domínguez, R.; Budaraju, S.; Roselló-Soto, E.; Barba, F.J; Mallikarjunan, K.; Roohinejad, S.; Lorenzo, J.M. Effect of innovative food processing technologies on the physicochemical and nutritional properties and quality of non-dairy plant-based beverages. Foods 2020, 9, 288. [CrossRef]

44. Sharma, P.; Oey, I.; Everett, D.W. Effect of pulsed electric field processing on the functional properties of bovine milk. Trends Food Sci. Technol. 2014, 35, 87-101. [CrossRef]

45. Sobrino-López, A.; Martín-Belloso, O. Potential of high-intensity pulsed electric field technology for milk processing. Food Eng. Rev. 2010, 2, 17-27. [CrossRef]

46. Arshad, R.N.; Abdul-Malek, Z.; Munir, A.; Buntat, Z.; Ahmad, M.H.; Jusoh, Y.M.; Bekhit, A.E.; Roobab, U.; Manzoor, M.F.; Aadil, R.M. Electrical systems for pulsed electric field applications in the food industry: An engineering perspective. Trends Food Sci. Technol. 2020, 104, 1-13. [CrossRef]

47. Soltanzadeh, M.; Peighambardoust, S.H.; Gullon, P.; Hesari, J.; Gullón, B.; Alirezalu, K.; Lorenzo, J. Quality aspects and safety of pulsed electric field (PEF) processing on dairy products: A comprehensive review. Food Rev. Int. 2020, 2020, 1-22. [CrossRef]

48. Sepulveda, D.R.; Góngora-Nieto, M.M.; Guerrero, J.A.; Barbosa-Cánovas, G.V. Shelf life of whole milk processed by pulsed electric fields in combination with PEF-generated heat. LWT 2009, 42, 735-739. [CrossRef]

49. Qin, B.-L.; Barbosa-Canovas, G.V.; Swanson, B.G.; Pedrow, P.D.; Olsen, R.G. Inactivating microorganisms using a pulsed electric field continuous treatment system. IEEE Trans. Ind. Appl. 1998, 34, 43-50.

50. Fernández-Molina, J.J. Inactivation of listeria innocua and pseudomonas fluorescens in skim milk treated with pulsed electric fields. In Pulsed Electric Fields in Food Processing. Fundamental Aspects and Applications; Barbosa-Ca'novas, G.V., Zhang, Q.H., Eds.; Technomic Publishing Company Inc: Lancaster, PA, USA, 2001; pp. 149-166.

51. Sobrino-López, A.; Martin-Belloso, O. Enhancing inactivation of Staphylococcus aureus in skim milk by combining high-intensity pulsed electric fields and nisin. J. Food Prot. 2006, 69, 345-353. [CrossRef]

52. Miranda, M.L.C. Inactivation of Listeria Innocua by Pulsed Electric Fields and Nisin; Washington State University: Pullman, WA, USA, 1998.

53. Guerrero-Beltrán, J.Á.; Sepulveda, D.R.; Góngora-Nieto, M.M.; Swanson, B.; Barbosa-Cánovas, G. Milk thermization by pulsed electric fields (PEF) and electrically induced heat. J. Food Eng. 2010, 100, 56-60. [CrossRef]

54. Sobrino-López, A.; Martín-Belloso, O. Enhancing the lethal effect of high intensity pulsed electric field in milk by antimicrobial compounds as combined hurdles. J. Dairy Sci. 2008, 91, 1759-1768. [CrossRef]

55. Ercan, S.S.; Soysal, C. Use of Ultrasound in Food Preservation. Nat. Sci. 2013, 5, 5-13. [CrossRef]

56. Ertugay, M.F.; Şengül, M.; Şengül, M. Effect of ultrasound treatment on milk homogenisation and particle size distribution of fat. Turk. J. Vet. Anim. 2004, 28, 303-308.

57. Alexandra, P. Bactericidal Effect of Ultrasound on the Microbiota of Raw Milk Cream. Adv. J. Food Sci. Technol. 2018, 15, 179-183. [CrossRef]

58. Juraga, E.; Sobota Šalamon, B.; Herceg, Z.; Režek Jambrak, A. Application of high intensity ultrasound treatment on Enterobacteriae count in milk. Mljekarstvo 2011, 61, 125-134.

59. Cregenzán-Alberti, O.; Halpin, R.M.; Whyte, P.; Lyng, J.; Noci, F. Suitability of ccRSM as a tool to predict inactivation and its kinetics for Escherichia coli, Staphylococcus aureus and Pseudomonas fluorescens in homogenized milk treated by manothermosonication (MTS). Food Control 2014, 39, 41-48. [CrossRef]

60. Herceg, Z.; Režek Jambrak, A.; Lelas, V.; Mededovic Thagard, S. The effect of high intensity ultrasound treatment on the amount of Staphylococcus aureus and Escherichia coli in milk. Food Technol. Biotechnol. 2012, 50, 46-52.

61. Cameron, M.; McMaster, L.D.; Britz, T.J. Impact of ultrasound on dairy spoilage microbes and milk components. Dairy Sci. Technol. 2009, 89, 83-98. [CrossRef]

62. Earnshaw, R.; Appleyard, J.; Hurst, R. Understanding physical inactivation processes: Combined preservation opportunities using heat, ultrasound and pressure. Int. J. Food Microbiol. 1995, 28, 197-219. [CrossRef]

63. Wrigley, D.M.; Llorca, N.G. Decrease of Salmonella typhimurium in skim milk and egg by heat and ultrasonic wave treatment. J. Food Prot. 1992, 55, 678-680. [CrossRef] [PubMed]

64. Zenker, M.; Heinz, V.; Knorr, D. Application of ultrasound assisted thermal processing for preservation and quality retention of liquid foods. J. Food Prot. 2003, 66, 1642-1649. [CrossRef] 
65. Potoroko, I.; Kalinina, I.; Botvinnikova, V.; Krasulya, O.; Fatkullin, R.; Bagale, U.; Sonawane, S.H. Ultrasound effects based on simulation of milk processing properties. Ultrason. Sonochem. 2018, 48, 463-472. [CrossRef]

66. Demirdöven, A.; Baysal, T. The use of ultrasound and combined technologies in food preservation. Food Rev. Int. 2008, 25, 1-11. [CrossRef]

67. Guneser, O.; Yuceer, Y.K. Effect of ultraviolet light on water-and fat-soluble vitamins in cow and goat milk. J. Dairy Sci. 2012, 95, 6230-6241. [CrossRef]

68. Falguera, V.; Pagán, J.; Ibarz, A. Effect of UV irradiation on enzymatic activities and physicochemical properties of apple juices from different varieties. LWT 2011, 44, 115-119. [CrossRef]

69. Choudhary, R.; Bandla, S. Ultraviolet pasteurization for food industry. Int. J. Food Sci. Nutr. Eng. 2012, 2, 12-15. [CrossRef]

70. Barba, F.J.; Koubaa, M.; do Prado-Silva, L.; Orlien, V.; de Souza Sant'Ana, A. Mild processing applied to the inactivation of the main foodborne bacterial pathogens: A review. Trends Food Sci. Technol. 2017, 66, 20-35. [CrossRef]

71. Datta, N.; Harimurugan, P.; Palombo, E.A. Ultraviolet and pulsed light technologies in dairy processing. Emerg. Dairy Process. Technol. 2015, 2015, 181-204. [CrossRef]

72. Jin, Y.; Hengl, N.; Baup, P.; Pignon, F.; Gondrexon, N.; Sztucki, M.; Gesan-Guiziou, G.; Magnin, A.; Abyan, M.; Karrouch, M.; et al. Effects of ultrasound on cross-flow ultrafiltration of skim milk: Characterization from macro-scale to nano-scale. J. Membr. Sci. 2014, 470, 205-218. [CrossRef]

73. Krishnamurthy, K.; Demirci, A.; Irudayaraj, J.M. Inactivation of Staphylococcus aureus in milk using flow-through pulsed UV-light treatment system. J. Food Sci. 2007, 72, 233-239. [CrossRef]

74. Matak, K.E.; Sumner, S.S.; Duncan, S.E.; Hovingh, E.; Worobo, R.W.; Hackney, C.R.; Pierson, M.D. Effects of ultraviolet irradiation on chemical and sensory properties of goat milk. J. Dairy Sci. 2007, 90, 3178-3186. [CrossRef]

75. Simmons, M.J.; Alberini, F.; Tsoligkas, A.N.; Gargiuli, J.; Parker, D.J.; Fryer, P.J.; Robinson, S. Development of a hydrodynamic model for the UV-C treatment of turbid food fluids in a novel 'SurePure turbulator ${ }^{\mathrm{TM}}$ 'swirl-tube reactor. Innov. Food Sci. Emerg. Technol. 2012, 14, 122-134. [CrossRef]

76. Reinemann, D.J.; Gouws, P.; Cilliers, T.; Houck, K.; Bishop, J.R. New methods for UV treatment of milk for improved food safety and product quality. in 2006 ASAE Annual Meeting. Am. Societ. Agricultur. Biol. Eng. 2006. [CrossRef]

77. Bandla, S.; Choudhary, R.; Watson, D.G.; Haddock, J. UV-C treatment of soymilk in coiled tube UV reactors for inactivation of Escherichia coli W1485 and Bacillus cereus endospores. LWT 2012, 46, 71-76. [CrossRef]

78. Nguyen, T.M.P.; Lee, Y.K.; Zhou, W. Effect of high intensity ultrasound on carbohydrate metabolism of bifidobacteria in milk fermentation. Food Chem. 2012, 130, 866-874. [CrossRef]

79. Körzendörfer, A.; Nöbel, S.; Hinrichs, J. Particle formation induced by sonication during yogurt fermentation-Impact of exopolysaccharide-producing starter cultures on physical properties. Int. Food Res. J. 2017, 97, 170-177. [CrossRef]

80. Shershenkov, B.; Suchkova, E. Upgrading the technology of functional dairy products by means of fermentation process ultrasonic intensification. Agron. Res. 2015, 13, 1074-1085.

81. Orlowska, M.; Koutchma, T.; Grapperhaus, M.; Gallagher, J.; Schaefer, R.; Defelice, C. Continuous and pulsed ultraviolet light for nonthermal treatment of liquid foods. Part 1: Effects on quality of fructose solution, apple juice, and milk. Food Bioproc. Technol. 2013, 6, 1580-1592. [CrossRef]

82. Fernández, A.; Thompson, A. The inactivation of Salmonella by cold atmospheric plasma treatment. Food Res. Int. 2012, 5, 678-684. [CrossRef]

83. Misra, N.N.; Koubaa, M.; Roohinejad, S.; Juliano, P.; Alpas, H.; Inácio, R.S.; Saraiva, J.A.; Barba, F.J. Landmarks in the historical development of twenty first century food processing technologies. Food Res. Int. 2017, 97, 318-339. [CrossRef]

84. Pankaj, S.K.; Shi, H.; Keener, K.M. A review of novel physical and chemical decontamination technologies for aflatoxin in Food. Trends Food Sci. Technol. 2018, 71, 73-83.

85. Phan, K.T.; Phan, H.T.; Brennan, C.S.; Phimolsiripol, Y. Nonthermal plasma for pesticide and microbial elimination on fruits and vegetables: An overview. Int. J. Food Sci. Technol. 2017, 52, 2127-2137. [CrossRef]

86. Thirumdas, R.; Sarangapani, C.; Annapure, U.S. Cold plasma: A novel non-thermal technology for food processing. Food Biophys. 2015, 10, 1-11. [CrossRef]

87. Misra, N.N.; Martynenko, A.; Chemat, F.; Paniwnyk, L.; Barba, F.J.; Jambrak, A.R. Thermodynamics, transport phenomena, and electrochemistry of external field-assisted nonthermal food technologies. Crit. Rev. Food Sci. Nutr. 2018, 58, 1832-1863. [CrossRef]

88. Liao, X.; Liu, D.; Xiang, Q.; Ahn, J.; Chen, S.; Ye, X.; Ding, T. Inactivation mechanisms of non-thermal plasma on microbes: A review. Food Cont. 2017, 75, 83-91.

89. Segat, A.; Misra, N.N.; Cullen, P.J.; Innocente, N. Effect of atmospheric pressure cold plasma (ACP) on activity and structure of alkaline phosphatase. Food Bioprod. Process. 2016, 98, 181-188. [CrossRef]

90. Ehlbeck, J.; Schnabel, U.; Polak, M.; Winter, J.; Von Woedtke, T.; Brandenburg, R.; Von dem Hagen, T.; Weltmann, K.D. Low temperature atmospheric pressure plasma sources for microbial decontamination. J. Phys. 2010, 44, 013002. [CrossRef]

91. Kim, H.J.; Yong, H.I.; Park, S.; Kim, K.; Choe, W.; Jo, C. Microbial safety and quality attributes of milk following treatment with atmospheric pressure encapsulated dielectric barrier discharge plasma. Food Control 2015, 47, 451-456. [CrossRef]

92. Ruan, R.; Deng, S.; Cheng, Y. Concentrated high intensity electric field (CHIEF) pasteurization of milk. Midwest Dairy Foods. Res. Cent. 2010, 2010, 183-188. 
93. Korachi, M.; Gurol, C.; Aslan, N. Atmospheric plasma discharge sterilization effects on whole cell fatty acid profiles of Escherichia coli and Staphylococcus aureus. J. Electrost. 2010, 68, 508-512. [CrossRef]

94. Korachi, M.; Aslan, N. The effect of atmospheric pressure plasma corona discharge on $\mathrm{pH}$, lipid content and DNA of bacterial cells. Plasma. Sci. Technol. 2011, 13, 99. [CrossRef]

95. Dave, A.; Walkling-Ribeiro, M.; Rodríguez-González, O.; Griffiths, M.W.; Corredig, M. Effect of PEF and UV and their combination on selected microorganisms and physicochemical properties in whey. J. Dairy Sci. 2012, 95, 168.

96. Sarangapani, C.; Devi, Y.; Thirundas, R.; Annapure, U.S.; Deshmukh, R.R. Effect of low-pressure plasma on physico-chemical properties of parboiled rice. LWT 2015, 63, 452-460. [CrossRef]

97. Kumar, P.; Sharma, N.; Ranjan, R.; Kumar, S.; Bhat, Z.F.; Jeong, D.K. Perspective of membrane technology in dairy industry: A review. Asian Australas. J. Anim. Sci. 2013, 26, 1347. [CrossRef]

98. Leeb, E.; Holder, A.; Letzel, T.; Cheison, S.C.; Kulozik, U.; Hinrichs, J. Fractionation of dairy based functional peptides using ion-exchange membrane adsorption chromatography and cross-flow electro membrane filtration. Int. Dairy J. 2014, 38, 116-123. [CrossRef]

99. Pafylias, I.; Cheryan, M.; Mehaia, M.A.; Saglam, N. Microfiltration of milk with ceramic membranes. Food Res. Int. 1996, 29, 141-146. [CrossRef]

100. Rodríguez-González, O.; Walkling-Ribeiro, M.; Jayaram, S.; Griffiths, M.W. Factors affecting the inactivation of the natural microbiota of milk processed by pulsed electric fields and cross-flow microfiltration. J. Dairy Res. 2011, 78, 270. [CrossRef] [PubMed]

101. Maubois, J. Membrane microfiltration: A tool for a new approach in dairy technology. Aust. J. Dairy Technol. $2002,57,92$.

102. Gosch, T.; Apprich, S.; Kneifel, W.; Novalin, S.A. A combination of microfiltration and high pressure treatment for the elimination of bacteria in bovine colostrum. Int. Dairy J. 2014, 34, 41-46. [CrossRef]

103. Daufin, G.; Escudier, J.P.; Carrère, H.; Bérot, S.; Fillaudeau, L.; Decloux, M. Recent and emerging applications of membrane processes in the food and dairy industry. Food Bioprod. Process. 2001, 79, 89-102. [CrossRef]

104. Caplan, Z.; Barbano, D. Shelf life of pasteurized microfiltered milk containing 2\% fat. J. Dairy Sci. 2013, 96, 8035-8046. [CrossRef] [PubMed]

105. Gesan-Guiziou, G. Removal of bacteria, spores and somatic cells from milk by centrifugation and microfiltration techniques. In Improving the Safety and Quality of Milk; Elsevier: Amsterdam, The Netherlands, 2010; pp. 349-372.

106. Elwell, M.; Barbano, D. Use of microfiltration to improve fluid milk quality. J. Dairy Sci. 2006, 89, 20-30. [CrossRef]

107. Trouvé, E.; Maubois, J.L.; Piot, M.; Madec, M.N.; Fauquant, J.; Rouault, A.; Tabard, J.; Brinkman, G. Retention of various microbial species during milk purification by cross-flow microfiltration. Lait 1991, 71, 1-13. [CrossRef]

108. Saboyainsta, L.V.; Maubois, J.L. Current developments of microfiltration technology in the dairy industry. Le Lait 2000, 80, 541-553. [CrossRef]

109. Brans, G.B.; Schroën, C.G.; Van der Sman, R.G.; Boom, R.M. Membrane fractionation of milk: State of the art and challenges. J. Membr. Sci. 2004, 243, 263-272. [CrossRef]

110. Paquin, P. Technological properties of high pressure homogenizers: The effect of fat globules, milk proteins, and polysaccharides. Int. Dairy J. 1999, 9, 329-335. [CrossRef]

111. Dalgleish, D.G.; Tosh, S.M.; West, S. Beyond homogenization: The formation of very small emulsion droplets during the processing of milk by a microfluidizer. Ned. Melk. En. Zuiveltijdschr. 1996, 50, 135-148.

112. Ciron, C.I.; Gee, V.L.; Kelly, A.L.; Auty, M.A. Effect of microfluidization of heat-treated milk on rheology and sensory properties of reduced fat yoghurt. Food Hydrocoll. 2011, 25, 1470-1476. [CrossRef]

113. Lemay, A.; Paquin, P.; Lacroix, C. Influence of microfluidization of milk on Cheddar cheese composition, color, texture, and yield. J. Dairy Sci. 1994, 77, 2870-2879. [CrossRef]

114. Van Hekken, D.L.; Tunick, M.H.; Malin, E.L.; Holsinger, V.H. Rheology and melt characterization of low-fat and full fat Mozzarella cheese made from microfluidized milk. LWT 2007, 40, 89-98. [CrossRef]

115. Amador-Espejo, G.G.; Suàrez-Berencia, A.; Juan, B.; Bárcenas, M.E.; Trujillo, A.J. Effect of moderate inlet temperatures in ultra-high-pressure homogenization treatments on physicochemical and sensory characteristics of milk. J. Dairy Sci. 2014, 97, 659-671. [CrossRef] [PubMed]

116. Juan, B.; Quevedo, J.; Guamis, B.; Ferragut, V.; Trujillo, A. Sensorial characteristics of goat milk cheeses made from ultra-highPressure homogenization-treated milk. In Proceedings of the 11 International Congress on Engineering and Food, Athens, Greece, 22 May 2009.

117. Serra, M.; Trujillo, A.J.; Guamis, B.; Ferragut, V. Flavour profiles and survival of starter cultures of yoghurt produced from high-pressure homogenized milk. Int. Dairy J. 2009, 19, 100-106. [CrossRef]

118. Zamora, A.; Juan, B.; Trujillo, A.J. Compositional and biochemical changes during cold storage of starter-free fresh cheeses made from ultra-high-pressure homogenised milk. Food Chem. 2015, 176, 433-440. [CrossRef] [PubMed]

119. Pereda, J.; Jaramillo, D.P.; Quevedo, J.M.; Ferragut, V.; Guamis, B.; Trujillo, A.J. Characterization of volatile compounds in ultra-high-pressure homogenized milk. Int. Dairy J. 2008, 18, 826-834. [CrossRef]

120. Amador-Espejo, G.G.; Gallardo-Chacón, J.J.; Juan, B.; Trujillo, A.J. Effect of ultra-high-pressure homogenization at moderate inlet temperatures on volatile profile of milk. J. Food Process. Eng. 2017, 40, e12548. [CrossRef] 
121. Bucci, A.J.; Van Hekken, D.L.; Tunick, M.H.; Renye, J.A.; Tomasula, P.M. The effects of microfluidization on the physical, microbial, chemical, and coagulation properties of milk. J. Dairy Sci. 2018, 101, 6990-7001. [CrossRef] [PubMed]

122. Tunick, M.H.; Van Hekken, D.L.; Cooke, P.H.; Smith, P.W.; Malin, E.L. Effect of high pressure microfluidization on microstructure of mozzarella cheese. LWT 2000, 33, 538-544. [CrossRef]

123. Olson, D.W.; White, C.H.; Watson, C.E. Properties of frozen dairy desserts processed by microfluidization of their mixes. J. Dairy Sci. 2003, 86, 1157-1162. [CrossRef]

124. Iordache, M.; Jelen, P. High pressure microfluidization treatment of heat denatured whey proteins for improved functionality. Innov. Food Sci. Emerg. Technol. 2003, 4, 367-376. [CrossRef]

125. Zhong, J.Z.; Liu, W.; Liu, C.M.; Wang, Q.H.; Li, T.; Tu, Z.C.; Luo, S.J.; Cai, X.F.; Xu, Y.J. Aggregation and conformational changes of bovine $\beta$-lactoglobulin subjected to dynamic high-pressure microfluidization in relation to antigenicity. J. Dairy Sci. 2012, 95, 4237-4245. [CrossRef]

126. Kamal, M.; Karoui, R. Analytical methods coupled with chemometric tools for determining the authenticity and detecting the adulteration of dairy products?: A review. Trends Food Sci. Technol. 2015, 46, 27-48. [CrossRef]

127. De Marchi, M.; Penasa, M.; Zidi, A.; Manuelian, C.L. Invited review: Use of infrared technologies for the assessment of dairy products-Applications and perspectives. J. Dairy Sci. 2018, 101, 10589-10604. [CrossRef] [PubMed]

128. Liu, N.; Parra, H.A.; Pustjens, A.; Hettinga, K.; Mongondry, P.; van Ruth, S.M. Evaluation of portable near-infrared spectroscopy for organic milk authentication. Talanta 2018, 184, 128-135. [CrossRef]

129. Brown, G. Quality Control using NIR/MIR Spectroscopy: A Rotten Apple Could Turn Your Product into a Lemon. IICA Tech Night Presentation, 9 December 2013.

130. Luiz, L.C.; Bell, M.J.V.; Rocha, R.A.; Leal, N.L.; Anjos, V.C. Detection of Veterinary Antimicrobial Residues in Milk through Near-Infrared Absorption Spectroscopy. J. Spectrosc. 2018, 2018, 1-6. [CrossRef]

131. Botelho, B.G.; Reis, N.; Oliveira, L.S.; Sena, M.M. Development and analytical validation of a screening method for simultaneous detection of five adulterants in raw milk using mid-infrared spectroscopy and PLS-DA. Food Chem. 2015, 181, 31-37. [CrossRef] [PubMed]

132. Gondim, C.S.; Junqueira, R.G.; Souza, S.V.C.; Ruisánchez, I.; Callao, M.P. Detection of several common adulterants in raw milk by MID-infrared spectroscopy and one-class and multi-class multivariate strategies. Food Chem. 2017, 230, 68-75. [CrossRef] [PubMed]

133. Sturaro, A.; De Marchi, M.; Masi, A.; Cassandro, M. Quantification of whey proteins by reversed phase-HPLC and effectiveness of mid-infrared spectroscopy for their rapid prediction in sweet whey. J. Dairy Sci. 2016, 99, 68-76. [CrossRef]

134. Andrade, J.; Pereira, C.G.; de Almeida, J.C.; Viana, C.C.R.; de Oliveira Neves, L.N.; da Silva, P.H.; Bell, M.J.; dos Anjos, V.D. FTIR-ATR determination of protein content to evaluate whey protein concentrate adulteration. LWT 2019, 99, 166-172. [CrossRef]

135. Ingle, P.D.; Christian, R.; Purohit, P.; Zarraga, V.; Handley, E.; Freel, K.; Abdo, S. Determination of protein content by NIR spectroscopy in protein powder mix products. J. AOAC Int. 2016, 99, 360-363. [CrossRef] [PubMed]

136. O'Loughlin, I.B.; Kelly, P.; Murray, B.A.; FitzGerald, R.J.; Brodkorb, A. Concentrated whey protein ingredients: A Fourier transformed infrared spectroscopy investigation of thermally induced denaturation. Int. J. Dairy Technol. 2015, 68, 349-356. [CrossRef]

137. Wang, T.; Tan, S.Y.; Mutilangi, W.; Aykas, D.P.; Rodriguez-Saona, L.E. Authentication of Whey Protein Powders by Portable Mid-Infrared Spectrometers Combined with Pattern Recognition Analysis. J. Food Sci. 2015, 80, 2111-2116. [CrossRef]

138. Kucheryavskiy, S.; Lomborg, C.J. Monitoring of whey quality with NIR spectroscopy-A feasibility study. Food Chem. 2015, 176, 271-277. [CrossRef] [PubMed]

139. Wang, K.; Sun, D.W.; Pu, H.; Wei, Q. Principles and applications of spectroscopic techniques for evaluating food protein conformational changes: A review. Trends Food Sci. Technol. 2017, 67, 207-219. [CrossRef] 